\title{
Expression of the gene encoding glycogen phosphorylase is elevated in diabetic rat skeletal muscle and is regulated by insulin and cyclic AMP
}

\author{
C.Reynet, C. R. Kahn, M. R. Loeken \\ Research Division, Joslin Diabetes Center, Boston, Massachusetts, USA
}

\begin{abstract}
Summary Glycogen phosphorylase regulates the breakdown of glycogen into glucose, but as previous studies have demonstrated, the control of glycogen metabolism becomes deregulated in diabetes mellitus. Messenger RNA levels encoding several different proteins are altered in skeletal muscle biopsies of patients with insulin-dependent and non-insulindependent diabetes. The possible alteration of expression of the gene encoding the skeletal muscle isoform of glycogen phosphorylase during diabetes has not previously been investigated. We examined the effect of streptozotocin-induced diabetes and insulin treatment on glycogen phosphorylase mRNA in rat skeletal muscle; glycogen phosphorylase mRNA levels were elevated in diabetic rat muscle tissue, but were partially suppressed in diabetic rat muscle following insulin treatment. To distinguish between the effects of insulin and counter-regulatory hormones on glycogen phosphorylase mRNA levels, we employed differentiating rat L 6 myoblasts in culture. In-
\end{abstract}

sulin stimulated the accumulation of glycogen phosphorylase mRNA as determined by Northern blot analysis. Moreover, insulin and dibutyryl cAMP stimulated expression of a transiently transfected chloramphenicol acetyl transferase reporter gene under the control of the muscle glycogen phosphorylase promoter in differentiating myotubes in culture, suggesting that the effects of insulin and counter-regulatory hormones on glycogen phosphorylase mRNA are at the level of transcription. These results suggest that insulin and epinephrine may participate in the induction of the glycogen phosphorylase gene during myogenesis; moreover, activation of this gene in muscle tissue may be a contributing factor in impaired glycogen storage during uncontrolled diabetes. [Diabetologia (1996) 39: 183-189]

Key words Glycogen phosphorylase, muscle, gene expression, insulin.
Glycogen stored in skeletal muscle is a major depot for metabolic fuel in the body $[1,2]$. The breakdown of the stored glycogen to provide muscle with metabolizable glucose is regulated by the enzyme glycogen

Received: 5 May 1995 and in revised form: 24 August 1995

Corresponding author: Dr. M. R. Loeken, Joslin Diabetes Center, One Joslin Place, Boston, MA 02215, USA

Abbreviations: CAT, Chloramphenicol acetyl transferase; GP, glycogen phosphorylase; GS, Glycogen synthase; STZ, streptozotocin; cAMP, cyclic AMP; db cAMP, dibutyryl cAMP; hGH, human growth hormone; EF1 $\gamma$, elongation factor gamma; bp, base pair; MEM, modified essential medium; DMEM, Dulbecco's modified essential medium; CREB, cAMP Response element binding protein. phosphorylase (GP). The activation by phosphorylation of GP enzyme activity has been widely studied and occurs in response to increased cAMP following the binding of epinephrine to its plasma membrane receptor [3]. Glycogen synthesis, on the other hand, is regulated by the enzyme glycogen synthase (GS). GS is stimulated by dephosphorylation which occurs in response to insulin [4].

Several studies have indicated that impaired glycogen storage and decreased GS activity occur during insulin resistance in both the non-insulin-dependent diabetic (NIDDM) and the pre-NIDDM individual [5-7]. The reduced insulin-responsive GS activity does not appear to be due to mutations in either the regulatory or coding regions of the muscle GS gene 
[8], but appears to correlate with reduced fasting and insulin-stimulated glycogen synthase phosphatase activity $[9,10]$. Because insulin inhibits cyclic AMP(cAMP) dependent protein kinase in skeletal muscle [11-14], and the inhibition of cAMP-dependent protein kinase is defective in insulin-resistant humans [15], the defect in glycogen storage appears to be due to impaired insulin signalling in muscle cells. Whether impaired insulin signalling could affect expression of the genes encoding either GS or GP has not previously been investigated.

To determine whether expression of the gene encoding the skeletal muscle isoform of GP might be affected by diabetes, we examined the level of GP mRNA in skeletal muscle obtained from streptozotocin (STZ)-treated diabetic rats, both with and without insulin treatment. To determine whether insulin itself could affect expression of the GP gene, we examined the effects of insulin, alone or in combination with a cAMP analogue, on GP mRNA accumulation and transcription directed by the GP promoter in cultured L6 myoblasts. These experiments demonstrate that expression of the gene encoding the skeletal muscle form of GP is under the control of hormones whose secretion or effects are altered during diabetes. Abnormal expression of the GP gene may contribute to impaired glycogen storage during diabetes.

\section{Materials and methods}

Cell culture. Rat L6 myoblasts [16] were grown in Eagle's Modified Essential Medium (MEM) containing $5.5 \mathrm{mmol} / \mathrm{l}$ glucose (Gibco/BRL Life Technologies, Grand Island, N. Y., USA). The media was supplemented with glutamine (Gibco) plus $10 \%$ donor calf serum (Gibco). Selection of fused myotubes was performed as described [17]. Briefly, media were replaced on each of days 5-9 of culture and $1 \mathrm{mmol} / 1$ cytosine arabinoside (Sigma, St. Louis, Mo., USA) was added on days 5, 7, and 9 of culture. Using this protocol, proliferating myoblasts were eliminated and fused myotubes survived. Unless otherwise noted, myoblast cultures were harvested before day 5 of culture, when cells were mononucleated and subconfluent. Prior to harvest of cultures, media were replaced with MEM plus $1 \%$ bovine serum albumin (Sigma) for $24 \mathrm{~h}$. Insulin (Eli Lilly, Indianapolis, Ind., USA) was added at $10^{-6} \mathrm{~mol} / 1$ to the indicated plates for the remainder of the culture period, as described.

Transfection and transient gene expression analysis. Cultures that were used for transfection were prepared as described above, with the following modifications. On day 4 of culture, media were replaced with Dulbecco's Modified Essential Medium (Gibco), containing $22.2 \mathrm{mmol} / \mathrm{l}$ glucose, plus $10 \%$ fetal calf serum (Sigma). Twelve $10-\mathrm{cm}$ culture dishes were each transfected for $16 \mathrm{~h}$ with $10 \mu \mathrm{g}$ of plasmid DNA encoding chloramphenicol acetyl transferase (CAT) enzyme and $5 \mu \mathrm{g}$ of plasmid DNA encoding human growth hormone (hGH) in $1 \mathrm{ml}$ of $\mathrm{CaPO}_{4}$ as described [18]. On day 5 of culture, the plates were washed once with MEM plus donor calf serum, then cells were removed from plates using $0.25 \%$ trypsin. Cells from all plates were pooled and diluted twofold into 24 fresh culture dishes in MEM containing donor calf serum. On days 8-12 of culture, half of the plates were selected for myotube formation, and the remaining myoblast cultures were prepared for treatment with cAMP analogue, insulin, or both.

Tests of effects of cAMP analogue and insulin were begun on day 8 of culture ( 3 days after replating) for plates containing myoblasts, and on day 15 of culture ( 10 days after replating) for plates containing myotubes. On these days, media were replaced with MEM plus $1 \%$ bovine serum albumin. Insulin was added at $10^{-6} \mathrm{~mol} / \mathrm{l}$ for the final $24 \mathrm{~h}$ of culture, and/or $2 \mathrm{mmol} / \mathrm{l}$ dibutyryl cAMP (db cAMP; Sigma) was added for the final $16 \mathrm{~h}$ of culture. The final day of myoblast culture was day 9 , and the final day of myotube culture was day 16 . Previous experiments have demonstrated that optimal stimulation of CAT enzyme expressed by transfected plasmid DNA in response to db cAMP occurs after $16 \mathrm{~h}$ of treatment [19]. At the end of each culture period, spent media were saved for assay of hGH and cells were scraped, sonicated, and saved for CAT enzyme assay. Human $\mathrm{GH}$ assays were performed by radioimmunoassay [20] using commercially available reagents (Nichols Institute, San Juan Capistrano, Calif., USA). Media were assayed using dilutions that would contain amounts of hGH within the limits of detection of the standard curve (0.5$50 \mathrm{ng} / 100 \mu \mathrm{l})$. Human $\mathrm{GH}$ secreted into media was expressed as $n g \mathrm{hGH} / 100 \mu \mathrm{l}$ of media. CAT assays were performed as described $[18,21]$ using amounts of cell extract that would contain CAT enzyme activity within the linear range of assay (1$60 \%$ ) during a 4 -h reaction. CAT activity was expressed as the per cent of total ${ }^{14} \mathrm{C}$-chloramphenicol (New England Nuclear, Boston, Mass., USA) which was acetylated by one half of the cell extract in a 4-h reaction. CAT activity from each plate was normalized by expressing the per cent CAT activity per ng $\mathrm{hGH}$ in $100 \mu \mathrm{l}$ spent media from the same plate. All treatments were performed in triplicate within each experiment and each experiment was repeated at least three times.

Animal procedures. Diabetic and insulin-treated diabetic rats were treated as described [22]. Briefly, male rats (130-180 g) were made diabetic with a single i.p. injection of $120 \mathrm{mg} / \mathrm{kg}$ STZ following an overnight fast. For the remainder of the experiment, animals were fed ad libitum. After 3 days, rats were screened for diabetes using blood glucose measurements. Some of the diabetic animals were injected with 2.5 IU of regular and $2.5 \mathrm{IU} \mathrm{NPH}$ insulin twice daily until day 7 following STZ treatment. Blood glucose measurements were made prior to the last insulin injection and just before killing. All animals were killed on day 7 following STZ treatment, which was $4 \mathrm{~h}$ after the last insulin injection. Immediately after killing, the hindlimb muscles were dissected from the animals and placed in liquid nitrogen to be saved for extraction of RNA. All animal procedures were in accordance with guidelines required by the National Institutes of Health and were approved by the Animal Care Committee of the Joslin Diabetes Center.

Preparation and analysis of RNA. RNA from rat muscle and L 6 cells were extracted by a modified guanidinium thiocyanate-phenol extraction procedure [23] using the commercially available reagent, RNAzol (Cinna Biotecx, Friendswood, Texas, USA) as described [24]. Northern blot analysis using $20 \mu \mathrm{g}$ of total RNA was performed as described [24]. The GP probe was made from a 0.5 kilobase Eco RI restriction fragment of a plasmid containing rat muscle glycogen phosphorylase cDNA [25]. The elongation factor probe was made from a pUC 120 plasmid containing elongation factor 1 gamma $(\mathrm{EF} 1 \gamma)$ cDNA. Probes were labelled with ${ }^{32} \mathrm{P}-\mathrm{dCTP}(3000 \mathrm{Ci} /$ 


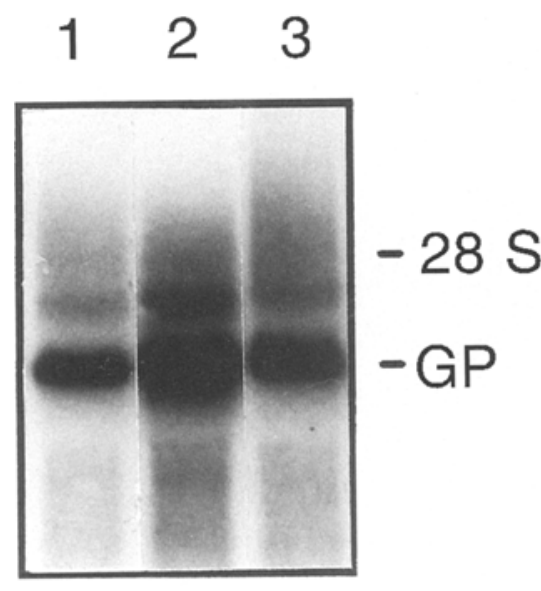

A

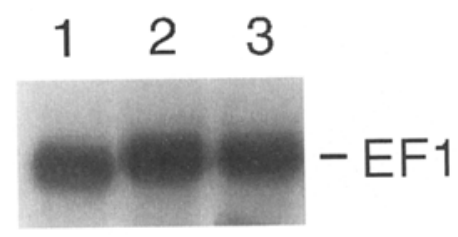

C

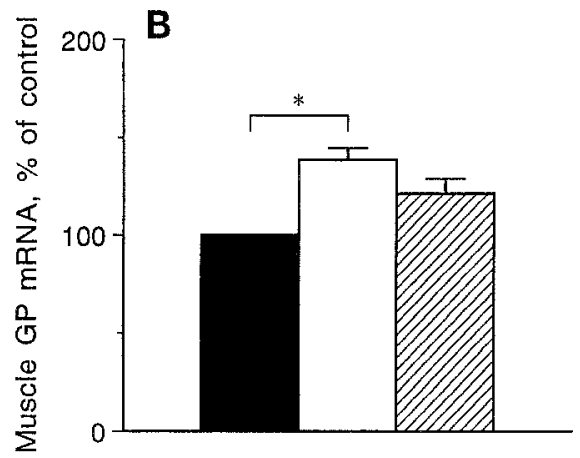

Fig. 1 (A-C). Northern blot analysis of rat muscle RNA probed with a rat muscle GP cDNA probe. (A) A representative Northern blot of muscle from three rats. Lane 1, control rat muscle; lane 2, muscle from STZ diabetic rat; lane 3, muscle from insulin-treated STZ diabetic rat. Northern blots were exposed to X-ray film overnight. (B) Scanning densitometry of Northern blots of hindlimb muscle from three control ( $\square$ ), four STZ diabetic $(\square)$, and four insulin-treated rats. Bars represent means \pm SEM of amount of GP mRNA detected by scanning densitometry when compared to control values, which were set at $100 \% .{ }^{*} p<0.001$.

(C) Northern blot analysis of the same RNA samples shown in A probed for EF1 $\gamma$ mmol) using random prime labelling (Amersham Arlington Heights, Ill., USA).

Plasmids. A plasmid containing part of the rat muscle glycogen phosphorylase cDNA [25] was obtained from Dr. J.Hudson (York University, Downsview, Ontario, Canada). A CAT plasmid containing the $5^{\prime}$ flanking sequence of the human muscle GP gene [26] was provided by Dr. J. Lockyer (Tulane University, New Orleans, LA, USA). The plasmid encoding hGH controlled by the mouse metallothionein promotor [27] is commercially available (Nichols Institute). A plasmid containing EF1 $\gamma$ cDNA was kindly provided by Dr. W. Moller (University of Leiden, Leiden, the Netherlands). All plasmids were prepared by two successive centrifugations in $\mathrm{CsCl}$-ethidium bromide gradients [28].

\section{Statistical analysis}

Data are presented as the means \pm SEM. Comparisons between control and treatment groups were made using an unpaired Student's $t$-test.

\section{Results}

GP $m R N A$ level is increased in skeletal muscle of diabetic rats. During subtraction hybridization of cDNA libraries made from muscle of non-diabetic and NIDDM humans, we detected altered abundance of clones encoding several proteins such as Rad, human elongation factor $1 \alpha$, myosin, myoglobin, a protein encoded by the mitochondrial genome, and GP [24,
Table 1. Body weight, plasma glucose, and serum insulin prior to killing of the rats whose hind limb RNA was used for assay of muscle GP RNA in Figure 1

\begin{tabular}{llll}
\hline & $\begin{array}{l}\text { Body weight } \\
(\mathrm{g})\end{array}$ & $\begin{array}{l}\text { Plasma glucose } \\
(\mathrm{mmol} / \mathrm{l})\end{array}$ & $\begin{array}{l}\text { Serum insulin } \\
(\mu \mathrm{U} / \mathrm{ml})\end{array}$ \\
\hline Control (3) & $201.7 \pm 1.7$ & $10.50 \pm 0.6$ & $20.0 \pm 7.8$ \\
STZ (4) & $163.8 \pm 6.3$ & $29.60 \pm 0.2$ & $4.5 \pm 2.1$ \\
STZ + Insulin (4) & $192.5 \pm 15.5$ & $3.85 \pm 1.17$ & $>1000$ \\
\hline
\end{tabular}

Values are the mean \pm SEM. The number of rats used for each measurement is indicated in parentheses

29]. Because the clone encoding GP was overexpressed in the cDNA library made from diabetic tissue, we hypothesize that diabetes might lead to increased expression of the GP gene. Potentially, this could alter the balance between glycogen storage and breakdown in diabetic muscle tissue.

To study the effect of diabetes on accumulation of GP mRNA in skeletal muscle, RNA was prepared from quadriceps muscle of rats that were made diabetic with STZ and were treated or not with insulin. Diabetic rats were hyperglycaemic and hypoinsulinaemic. Insulin treatment of diabetic rats reduced blood glucose levels to within normal range (Table 1). Northern blot analysis demonstrated that GP mRNA was elevated in the skeletal muscle of diabetic, hypoinsulinaemic rats and that insulin treatment of diabetic rats reduced GP mRNA (Fig. $1 \mathrm{~A}$ and $\mathrm{B}$ ). In contrast, expression of $\mathrm{EF} 1 \gamma$, unlike elongation $1 \alpha$ [29] or GP, was unchanged by either diabetes or insulin 
treatment (Fig. 1 C). These results suggest that poorly controlled diabetes results in increased accumulation of skeletal muscle GP mRNA, and that treatment of the diabetes restores the level of GP mRNA to approximately that of non-diabetic muscle tissue.

Effects of insulin on accumulation of GP $m R N A$ during myoblast differentiation. The increase in GP mRNA during STZ diabetes and subsequent decrease during insulin treatment of the diabetes could be due to effects of insulin, counter-regulatory hormones, glucose, or a combination of these factors, on GP mRNA synthesis and/or turnover. To determine whether insulin or counter-regulatory hormones, as exemplified by db cAMP, could individually affect GP gene expression, we employed differentiating rat L6 myoblasts. We first examined whether insulin alone had any effect on GP mRNA accumulation. During differentiation, L 6 cells develop high-affinity insulin binding sites and insulin responsive 2-deoxyD-glucose and $\alpha$-aminoisobutyric acid uptake [17]. Thus, if insulin has any effect on GP mRNA synthesis or turnover, this should be demonstrable during differentiation of L 6 cells in culture.

To test for insulin effects on GP mRNA accumulation, serum-containing media were replaced with serum-free media containing $1 \%$ bovine serum albumin for $24 \mathrm{~h}$, followed by either no insulin or addition of $10^{-6} \mathrm{~mol} / \mathrm{l}$ insulin for the final $6 \mathrm{~h}$ of culture. Beginning on day 7 of culture, cells were harvested and RNA was extracted to be used for Northern blot analysis. Skeletal muscle GP mRNA was undetectable on day 7 of culture, and little, if any, GP mRNA could be detected by Northern blot analysis at any time during 10 days in unselected cultures which contained predominantly myoblasts (Fig. 2). In contrast, insulin stimulated GP mRNA accumulation on days 9 and 10 of culture in plates containing myotubes. Thus, insulin promotes skeletal muscle GP mRNA accumulation in cultured L6 myotubes, but did not appear to stimulate GP expression in myoblasts. To determine the time course for optimal accumulation of GP mRNA in response to insulin by these cells, myotube cultures were serum starved overnight, and then treated with $10^{-6} \mathrm{~mol} / \mathrm{l}$ insulin for between $30 \mathrm{~min}$ and $48 \mathrm{~h}$. As shown in Figure 3, insulin stimulation of GP mRNA accumulation could first be detected after $5 \mathrm{~h}$, and remained elevated for at least $48 \mathrm{~h}$. Because strong expression could be observed at $24 \mathrm{~h}$, insulin treatment of L 6 cells for $24 \mathrm{~h}$ was used in subsequent experiments.

Effects of insulin and cAMP on transcription directed by the skeletal muscle GP promoter. To determine whether changes in GP mRNA levels were due to transcription directed by the GP promoter, a plasmid containing a CAT reporter gene linked to 1129 bp of $5^{\prime}$ flanking sequence of the human skeletal muscle

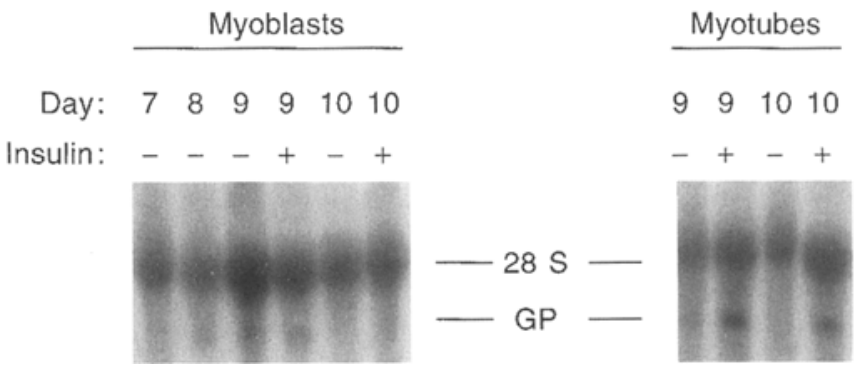

Fig. 2. Northern blot analysis of RNA from L 6 cells using a rat muscle GP cDNA probe. Cultures of myoblasts were harvested on days $7-10$, and cultures of myotubes were harvested on days 9 and 10, after induction of differentiation. Cultures that were treated with $10^{-6} \mathrm{~mol} / \mathrm{l}$ insulin for the final $6 \mathrm{~h}$ of culture are indicated. Northern blots were exposed to X-ray film for 10 days. The positions of $28 \mathrm{~S}$ ribosomal RNA and GP mRNA are indicated.

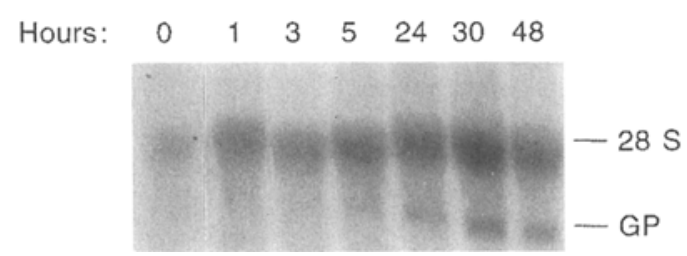

Fig.3. Time course of insulin stimulation of GP mRNA accumulation in L6 myotube cultures. Cultures were grown in serum-free medium for $24 \mathrm{~h}$, followed by insulin treatment for 0 $48 \mathrm{~h}$. Blots were probed and exposed as described for Figure 2

GP gene was transfected into L6 myoblasts. During rat [30] and human [26] fetal muscle development, muscle-specific GP is induced to replace the braintype GP isozyme. The expression of the muscle GP isozyme gene depends on a muscle-specific transcription control element within the 1129 bp 5 ' flanking region of the gene [26]. A plasmid containing the mouse metallothionein promoter linked to an $\mathrm{hGH}$ reporter gene was co-transfected as an internal control to correct for the difference in numbers of cells per plate containing myoblasts or myotubes. Cells were harvested either while they were still myoblasts, or were treated to select for differentiation into myotubes. The results of these experiments are shown in Figure 4 . In both myoblast and myotube cultures, there was significant stimulation of CAT activity upon treatment with $\mathrm{db}$ cAMP. In myotube cultures, there was also significant stimulation of CAT activity by insulin. Moreover, in myotube cultures, treatment with $\mathrm{db}$ cAMP and insulin in combination stimulated CAT enzyme production to greater levels than did either treatment alone. Deletion analysis of GP promoter mutants has demonstrated that the muscle-specific element responsible for elevated GP expression in differentiated myotubes is present between $\mathrm{nt}$ -570 and $-612[26]$. We found, however, that a plasmid containing only 96 bp of GP promoter sequence was responsive to db cAMP and insulin (Fig. 4C) similar 

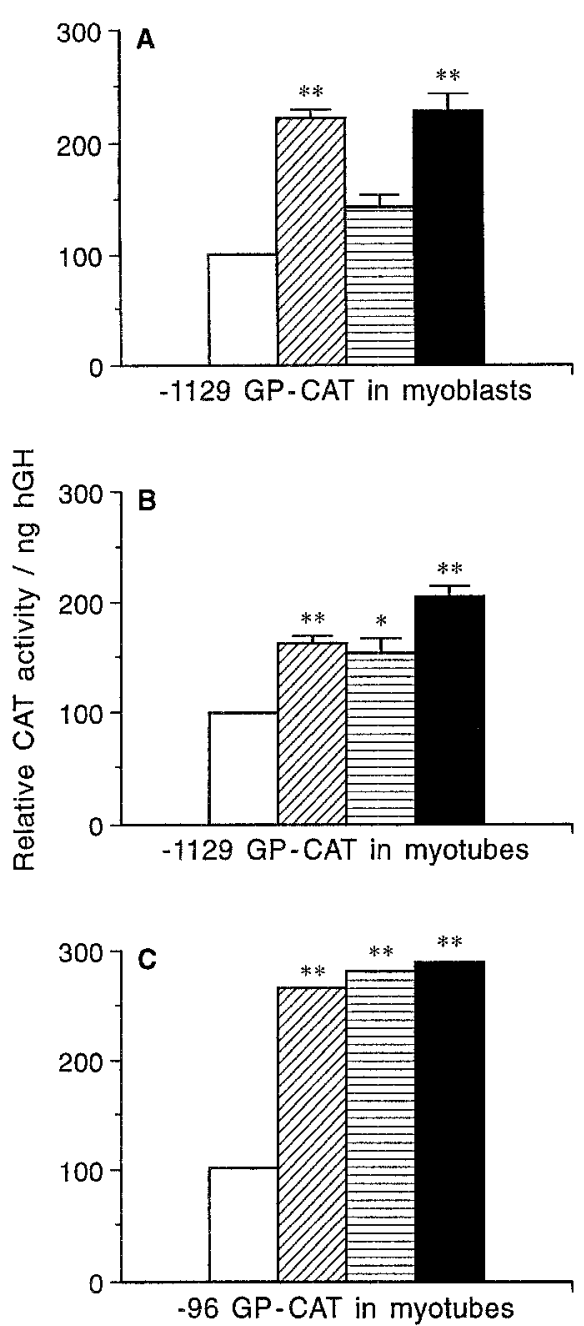

Fig. 4 (A-C). CAT enzyme activity expressed under the direction of the human muscle GP promoter in L6 myoblast (A) and myotube (B and $\mathbf{C}$ ) cultures. Cultures were grown for the final $48 \mathrm{~h}$ in serum-free medium, then treated with insulin for the final $24 \mathrm{~h}$ and/or db cAMP for the final $16 \mathrm{~h}$ as described in the text. The amount of CAT enzyme activity produced by each culture dish was corrected for the amount of hGH production by a co-transfected internal standard plasmid, then were expressed relative to the CAT activity/ng hGH in untreated (basal) cultures, which was set at $100 \%$. The data presented in $\mathbf{A}$ and $\mathbf{B}$ represent the means \pm SEM of the corrected CAT enzyme activity from three repeated experiments, each performed with triplicate plates for each treatment. The data shown in $\mathbf{C}$ represent the means of corrected CAT activity from three repeated experiments, each performed with one plate for each treatment. Significance of the differences of each insulin or db cAMP treated culture from control cultures, $* p<0.05, * * p<0.005 \square$, Basal; $\mathbb{Z}$, db cAMP; 囬, insulin; db cAMP + insulin

to the plasmid containing the entire $1129 \mathrm{bp}$ of the GP promoter (Fig.4B), and so the muscle-specific element is not required in order for $\mathrm{db}$ cAMP and insulin to activate transcription in myotube cultures.

As shown in Table 2, in which the amount of hGH secreted by cells from one experiment is displayed, there was significantly less hGH produced by myotube than myoblast cultures, due to the reduction of
Table 2. The amount of radioimmunoassayable hGH per $100 \mu$ l of culture media

\begin{tabular}{lll}
\hline & & hGH (ng) \\
\hline Myoblasts & - & $110.0 \pm 6.23$ \\
& db cAMP & $109.6 \pm 9.0$ \\
& Insulin & $101.9 \pm 5.8$ \\
Myotubes & db cAMP + Insulin & $102.4 \pm 3.6$ \\
& - & $13.4 \pm 0.9$ \\
& db cAMP & $12.3 \pm 0.5$ \\
& Insulin & $14.6 \pm 0.2$ \\
& db cAMP + Insulin & $14.0 \pm 0.5$ \\
\hline
\end{tabular}

Values represent the mean \pm SEM of three replicate culture dishes from one of the experiments used in Figure $4 \mathrm{~A}$ and $\mathrm{B}$

cells during differentiation of myotubes. There was not, however, any effect of either insulin or $\mathrm{db}$ cAMP, added individually or together, on the levels of hGH produced by either myoblast or myotube cultures. Therefore, when the number of transfected cells at the time of harvest was corrected for, there were significant stimulatory effects of $\mathrm{db}$ cAMP and insulin on the skeletal muscle GP promoter, but neither treatment affected transcription directed by the internal control metallothionein promoter.

\section{Discussion}

Preliminary data suggesting that diabetes may increase skeletal muscle GP mRNA levels in humans led us to investigate whether GP mRNA levels might be affected in an animal model of diabetes, and, if so, to examine the mechanism of this regulation. Our results indicate that the level of skeletal muscle GP mRNA is elevated in rodents under conditions of insulin insufficiency (i.e. STZ-diabetes) and that insulin treatment at least partially restores GP mRNA to control levels.

A difficulty in interpreting these results is that STZ diabetes and insulin treatment of the diabetes was associated with alterations in the levels of several hormones, and glucose, in addition to insulin. Thus, it was not possible, using the intact animal, to determine whether insulin or any other hormone was directly or indirectly responsible for changes in GP gene expression in skeletal muscle. To circumvent this problem, we employed a muscle-cell culture model where the effects of insulin and a cAMP analogue, which would mimic the effects of epinephrine, could be studied individually and in combination, and without alterations in glucose concentrations. Insulin treatment alone could stimulate accumulation of GP mRNA in L6 cells. Differentiation of these cells into myotubes was essential before GP mRNA could be detected and an insulin stimulatory effect could be observed. CAT assay of the muscle GP promoter, which provided direct evidence for transcrip- 
tion controlled by the GP promoter and was more sensitive than Northern blot analysis of GP mRNA, suggested that effects of insulin were at the level of transcription of the skeletal muscle GP gene. Insulin stimulation of the GP promoter was observed in both myoblast and myotube cultures. Although the magnitude of stimulation by insulin was similar before and after differentiation, the greater transcriptional activity of the GP promoter in myotube cultures appears to explain the requirement for differentiation in order to observe stimulation of GP mRNA by insulin using Northern blot analysis.

Use of L6 cells further demonstrated that activation of a cAMP-dependent pathway could stimulate increased transcription directed by the GP promoter. This suggests that elevation of GP mRNA in the muscle of STZ-diabetic rats was in response to increased secretion of epinephrine during diabetes. Likewise, the decrease in muscle GP mRNA levels following insulin treatment of diabetes may result from reduced production of epinephrine as a consequence of insulin administration and adjustment of blood glucose levels. Thus, regulation of the GP gene by epinephrine alone may be sufficient to explain the changes in GP mRNA during diabetes and insulin administration.

Although we obtained evidence for insulin regulation of GP transcription in cultured L 6 cells, it is not clear whether insulin has any direct effect on transcription of the GP gene in terminally differentiated muscle in the intact animal. It is possible to reconcile the apparent differences of insulin treatment on GP gene expression in cultured L 6 cells and in muscle tissue if insulin has one effect during differentiation of muscle, as manifested in L 6 cultures, and another effect on terminally differentiated muscle, as manifested in rat tissue. Insulin, perhaps by binding to the insulin-like growth factor-I receptor, appears to promote muscle differentiation [31]. Therefore, insulin may induce the GP gene as it stimulates myoblast differentiation. Although L6 myotube cultures display many of the characteristics of differentiated muscle, transformation of L6 cells may preclude manifestation of some of the characteristics of terminally differentiated muscle tissue. It should be noted that we obtained similar results using another transformed muscle cell line, rat tc-2 cells [32], in which insulin also stimulated GP mRNA accumulation and GPCATenzyme production (data not shown). Following terminal differentiation, insulin may lose its effect on transcription regulation of the GP gene. Cyclic AMPdependent mechanisms, on the other hand, may remain operational. Alternatively, insulin may acquire a different mechanism for regulating the GP gene which is inhibitory rather than stimulatory.

At this stage of the research, we can only speculate about the mechanisms by which insulin regulates GP gene expression in either L6 cells or muscle tissue. The $1129 \mathrm{bp}$ of the skeletal muscle GP promoter [26] did not contain the 10-bp insulin response sequence contained in any of 10 insulin-responsive genes [33]. The closest similarity to any previously identified insulin response sequence was a 10-bp sequence beginning at $\mathrm{nt}-352$ that differed from the glucokinase insulin response sequence by 2 bp [34]. Although the glucokinase gene is stimulated by insulin, it is unlikely that this element is involved in the insulin stimulation of the GP gene in differentiating myoblasts, as CAT plasmids that contain only 96 bp of $5^{\prime}$ flanking sequence from the GP promoter were also stimulated by insulin. Thus, if the effect of insulin on GP transcription in either differentiating or terminally differentiated muscle is mediated by the binding of an insulin-responsive transcription factor to $5^{\prime}$ flanking sequences of the GP gene, is likely to recognize a different element from those contained in the insulin responsive genes mentioned above. However, insulin could affect the activation of transcription factors involved in other hormonal pathways. For example, insulin could affect modification of the cAMP response element binding protein, CREB, $[35,36]$ as it does in cultured hepatoma cells [37]. There are multiple elements within the GP promoter that resemble the consensus sequence for CREB, TGACGTCA [38], including one starting at nt -90 . Future experiments examining transcription factors that bind to the muscle GP promoter will be necessary to understand how insulin regulates this gene.

Our results provide the first evidence that expression of the skeletal muscle form of GP is increased during diabetes and that it is under transcriptional control by hormones. The elevation in GP mRNA that occurs during diabetes may be due to direct effects of epinephrine, and perhaps insulin. Because impaired glycogen metabolism is a hallmark of insulin resistance and poorly controlled diabetes, study of the regulation of the skeletal muscle GP gene is important to understand how glycogen synthesis and breakdown are controlled.

Acknowledgements. We are grateful to Dr. M.Saad for assistance with experiments using rat muscle tissue, to Ms. M. Petruzzelli for assistance in the care of diabetic rats, and to Dr. R. Smith for advice on the culture of L 6 cells. The technical assistance of Ms. J. Guerin is appreciated. M. R. L. was supported in part by an award from the Capps Foundation for Diabetes Research and by a grant from the National Institutes of Health (CA 50599). C.R.K. was supported by a grant from the National Institutes of Health (DK 45935). C. R. was supported by a fellowship from the Juvenile Diabetes Foundation and by an award from ALFEDIAM.

\section{References}

1. Kelley D, Mitrakou A, Marsh H et al (1988) Skeletal muscle glycolysis, oxidation, and storage of an oral glucose load. J Clin Invest 81: 1563-1571

2. DeFronzo R, Gunnarsson R, Bjorkman O, Olsson M, Wahren J (1985) Effects of insulin on peripheral and splanchnic 
glucose metabolism in noninsulin-dependent (type II) diabetes mellitus. J Clin Invest 76: 149-155

3. Sutherland EW, Oye I, Butcher RW (1965) The action of epinephrine and the role of the adenyl cyclase system in hormone action. Recent Progr Hormone Res 21: 623-646

4. Craig JW, Larner J (1964) Influence of epinephrine and insulin on uridine diphosphate glucose-alpha-glucan transferase and phosphorylase in muscle. Nature 202: 971-973

5. Johnson AB, Argyraki M, Thow JC, Broughton D, Jones IR, Taylor R (1990) Effects of intensive dietary treatment on insulin-stimulated skeletal muscle glycogen synthase activation and insulin secretion in newly presenting type $2 \mathrm{di}$ abetic patients. Diabet Med 7: 420-428

6. Bogardus C, Lillioja S, Stone K, Mott D (1984) Correlation between muscle glycogen synthase activity and in vivo insulin action in man. J Clin Invest 73: 1185-1190

7. Thorburn AW, Gumbiner B, Bulacan F, Brechtel G, Henry RR (1991) Multiple defects in muscle glycogen synthase activity contribute to reduced glycogen synthesis in non-insulin dependent diabetes mellitus. J Clin Invest 87:489-495

8. Bjorbaek C, Echwald SM, Hubricht P et al (1994) Genetic variants in promoters and coding regions of the muscle glycogen synthase and the insulin-responsive GLUT 4 genes in NIDDM. Diabetes 43: 976-983

9. Freymond D, Bogardus C, Okubo M, Stone K, Mott D (1988) Impaired insulin-stimulated muscle glycogen synthase activation in vivo in man is related to low fasting glycogen synthase phosphatase activity. J Clin Invest 82: 1503-1509

10. Kida Y, Esposito-Del Puente A, Bogardus C, Mott DM (1990) Insulin resistance is associated with reduced fasting and insulin-stimulated glycogen synthase phosphatase activity in human skeletal muscle. J Clin Invest 85: 476-481

11. Walkenbach RJ, Hazen R, Larner J (1980) Hormonal regulation of glycogen synthase. Insulin decreases protein kinase sensitivity to cyclic AMP. Biochim Biophys Acta 629: $421-430$

12. Okubo M, Bogardus C, Lillioja S, Mott DM (1989) Adenosine $3^{\prime}, 5^{\prime}$-monophosphate-dependent protein kinase activity decreases in human muscle after insulin infusion. $J$ Clin Endocrinol Metab 69: 798-803

13. Torres HN, Marechal LR, Bernard E, Belocopitow E (1968) Control of muscle glycogen phosphorylase activity by insulin. Biochim Biophys Acta 156: 206-209

14. Shen LC, Villar-Palisi C, Larner J (1970) Hormonal alteration of protein kinase sensitivity to $3^{\prime} 5^{\prime}$-cyclic AMP. Physiol Chem Phys 2: 536-544

15. Kida Y, Nyomba BL, Bogardus C, Mott DM (1991) Defective insulin response of cyclic adenosine monophosphatedependent protein kinase in insulin-resistant humans. $J$ Clin Invest 87: 673-679

16. Yaffe D (1968) Retention of differentiation potentialities during prolonged cultivation of myogenic cells. Proc Natl Acad Sci USA 61: 477-483

17. Beguinot F, Kahn CR, Moses AC, Smith RJ (1986) The development of insulin receptors and responsiveness is an early marker of differentiation in the muscle cell line L6. Endocrinology 118: 446-455

18. Loeken MR, Khoury G, Brady J (1986) Stimulation of the adenovirus E2 promoter by simian virus $40 \mathrm{~T}$ antigen or E1A occurs by different mechanisms. Mol Cell Biol 6: 2020-2026

19. Loeken MR (1993) Effects of mutation of the CREB binding site of the somatostatin promoter on cyclic AMP responsiveness in CV-1 cells. Gene Expression 3: 253-264

20. Selden RF (1987) Assay for human growth hormone. Current protocols in molecular biology. Greene Publishing Associates, New York, 9.7.1-2
21. Gorman CM, Moffat LF, Howard BH (1983) Recombinant genomes which express chloramphenicol acetyl transferase in mammalian cells. Mol Cell Biol 2: 1044-1051

22. Saad MJA, Araki E, Miralpeix M, Rothenberg PL, White MF, Kahn CR (1992) Regulation of insulin receptor substrate-1 in liver and muscle of animal models of insulin resistance. J Clin Invest 90: 1839-1849

23. Chomczynski P, Sacchi N (1987) Single-step method of RNA isolation by guanidinium thiocyanate-phenol-chloroform extraction. Anal Biochem 162: 156-159

24. Reynet C, Kahn CR (1993) Rad: a member of the ras family overexpressed in muscle of type II diabetic humans. Science 262: 1441-1444

25. Hwang PK, See YP, Vincentini AM, Powers MA, Fletterick RJ, Crerar MM (1985) Comparative sequence analysis of rat, rabbit, and human muscle glycogen phosphorylase cDNAs. Eur J Biochem 152: 267-274

26. Lockyer JM, McCracken Jr JB (1991) Identification of a tissue-specific regulatory element within the human muscle glycogen phosphorylase gene. J Biol Chem 266: 2026220269

27. Selden RF, Burke-Howie K, Rowe ME, Goodman HM, Moore DD (1986) Human growth hormone as a reporter gene in regulation studies employing transient gene expression. Mol Cell Biol 6: 3173-3179

28. Maniatis T, Fritsch EF, Sambrook J (1982) Molecular cloning: a laboratory manual. Cold Spring Harbor Laboratory, Cold Spring Harbor, New York

29. Kahn CR, Reynet C (1994) Identification of diabetes-related genes by subtraction cloning. Molecular biology of diabetes. Humana Press, Totowa, New Jersey, pp 51-77

30. David E, Crerar MM (1986) Quantitation of muscle glycogen phosphorylase mRNA and enzyme amounts in adult rat tissues. Biochim Biophys Acta 880: 78-90

31. Ewton DA, Falen SL, Florini JR (1987) The type II insulinlike growth factor (IGF) receptor has low affinity for IGF-I analogs: pleiotypic actions of IGFs on myoblasts are apparently mediated by the type I receptor. Endocrinology 120 : $115-123$

32. Iujvidin S, Fuchs O, Nudel U, Yaffe D (1990) SV 40 immortalizes myogenic cells: DNA synthesis and mitosis in differentiating myotubes. Differentiation 43: 192-203

33. O'Brien RM, Bonovich MT, Forest CD, Granner DK (1991) Signal transduction convergence: phorbol esters and insulin inhibit phosphoenolpyruvate carboxykinase gene transcription through the same 10-base-pair sequence. Proc Natl Acad Sci USA 88: 6580-6584

34. Magnuson MA, Andreone TL, Printz RL, Kach S, Granner DK (1989) The glucokinase gene: structure and regulation by insulin. Proc Natl Acad Sci USA 86: 4838-4842

35. Hoeffler JP, Meyer TE, Yun Y, Jameson JL, Habener JF (1988) Cyclic AMP-responsive DNA-binding protein: structure based on a cloned placental cDNA. Science 242: $1430-1433$

36. Gonzalez GA, Yamamoto KK, Fischer WH et al (1989) A cluster of phosphorylation sites on the cyclic AMP-regulated nuclear factor CREB predicted by its sequence. $\mathrm{Na-}$ ture 337: 749-752

37. Quinn PG (1994) Inhibition by insulin of protein kinase Ainduced transcription of the phosphoenolpyruvate carboxykinase gene-mediation by the activation domain of cAMP esponse element-binding protein (CREB) and factors bound to the TATA box. J Biol Chem 269: 14375-14378

38. Montminy MR, Sevarino KA, Wagner JA, Mandel G, Goodman RH (1986) Identification of a cyclic-AMP-responsive element within the rat somatostatin gene. Proc Natl Acad Sci USA 83: 6682-6686 